\title{
Survey on the Acquisition of Villagers Under the Implementation of Coal to Electricity (Gas) Policy in Rural Areas: Based on Rural Areas in Baoding
}

\author{
Zheng-tao PENG \\ The second Campus of North China Electric Power University \\ Baoding, Hebei, China
}

Keywords: Coal to Electricity; Coal to Gas; Sense of Gain; Suggestions.

\begin{abstract}
To solve the problem of smog, China has successively introduced a series of coal-to- gas reform policies, which are being implemented in many parts of the country. In the implementation of polices, the degree of people's sense of acquisition is not high, especially the people in the rural areas are dissatisfied with the two policies of coal-to-gas and coal-to-electricity. Based on the phenomenon of dissatisfaction among farmers, this study separately investigated the implementation of coal-to-gas conversion in economic and ecological life. It explains the survey of farmers' sense of acquisition and proposes corresponding countermeasures to better promote the implementation of these two policies.
\end{abstract}

\section{Introduction}

In recent years, haze in winter has been severe in most parts of China. In particular, air pollution has become more serious in northern regions. Hazy weather has seriously affected people's production and life. Solving haze problems is imminent. In winter, coal-fired heating is an important cause of hazy weather. In order to solve the increasingly serious problem of atmospheric pollution, the project of retrofitting coal-fired boilers into natural-gas-fired has been put into practice, which is one of the clean energy actions for the main districts of China.

The implementation of the policy, the degree of people's sense of acquisition is not high, especially the people in the rural areas are dissatisfied with the two policies of coal-to-gas and coal-to-electricity.

The "sense of gain" has great practical significance for the development of contemporary society. In terms of individuals, a sense of acquisition is conducive to promoting people's all-round development and self-transcendence. At the same time, it is conducive to solving real problems and improving individual happiness index. In terms of society, the "feeling of gain" is beneficial to avoiding the phenomenon of materialization in society and forming a correct view of justice and benefit in terms of the state, the proposal of "a sense of acquisition" is conducive to enhancing the self-confidence and cohesion of the nation, and promoting social harmony and stability.

The evaluation of employees' sense of achievement covers five dimensions: economic life, political life, cultural life, social life, and ecological life. But the sense of environmental access generally involves only economic life and environmental life.

\section{Methodology}

\subsection{Dependent variable settings}

In the variable setting, we simply divide it into the dependent variable and the independent variable. In the relevant variable setting, the dependent variable of this study is the measurement of the sense of acquisition, and the evaluation of the employee's sense of acquisition covers five dimensions economic life, political life, cultural life, social life and ecological life. Among them, the weight of economic life influencing factors accounted for $33.06 \%$, the weight of political life influencing factors accounted for $18.18 \%$, the weight of cultural life influencing factors accounted for $10.68 \%$, the weight of social life influencing factors was $26.44 \%$, and the weight of ecological life influencing factors accounted for $11.64 \%$. Among them, the economic factor account for the 
largest proportion, one-third of the factors affecting the month, and the cultural influence factors are the lowest.

Table 1. Workers' sense of achievement index system (Numbers represent weights)

\begin{tabular}{l|l|l|l|l}
\hline \multirow{4}{*}{$\begin{array}{l}\text { Sense } \\
\text { of gain }\end{array}$} & Economic & $\begin{array}{l}\text { Economic } \\
\text { levelopment 0.2641 }\end{array}$ & GDP per capita 0.3333 & $\begin{array}{l}\text { Annual growth rate of } \\
\text { GDP Per capita 0.6667 }\end{array}$ \\
\cline { 2 - 5 } & Wages 0.4045 & $\begin{array}{l}\text { Per capita disposable } \\
\text { income 0.3333 }\end{array}$ & $\begin{array}{l}\text { Salary increase rate } \\
0.6667\end{array}$ \\
\cline { 2 - 5 } & \multirow{2}{*}{$\begin{array}{l}\text { Ecological } \\
\text { life }\end{array}$} & $\begin{array}{l}\text { Environmental } \\
\text { resources 0.4231 }\end{array}$ & Forest cover rate 0.2134 & $\begin{array}{l}\text { Built-up area green } \\
\text { coverage 0.4123 }\end{array}$ \\
\cline { 2 - 5 } & $\begin{array}{l}\text { Environmental } \\
\text { governance 0.5769 }\end{array}$ & $\begin{array}{l}\text { Excellent air quality } \\
\text { days } 0.5123\end{array}$ & $\begin{array}{l}\text { PM2.5 average annual } \\
\text { concentration 0.1755 }\end{array}$ \\
\hline
\end{tabular}

The change in coal-to-electricity (gas) policy is mainly based on the choice of economic life and ecological life as independent variables. The economic life is mainly determined by the economic development, the wage level. The weights they decide on economic life are $0.2641,0.4045$ respectively, as shown in Table 1.

It can be found that wage levels and economic development have a decisive effect on economic life. Therefore, economic development and wage levels are taken as a basis for measuring economic life.

Ecological life is taken as the second independent variable, which is determined by the joint measurement of environmental resources and environmental governance. Among them, environmental governance accounts for absolute influence factors, so this study takes environmental governance as a measure of ecological life. Environmental management is determined by the number of days with good air quality, the harmless treatment rate of domestic garbage, and the average annual concentration of PM2.5, as shown in Table 1. However, in this study, environmental governance was mainly measured by the number of days with good air quality and the average annual concentration of PM2.5.

\subsection{Research hypothesis}

Hypothesis A: Economic life has an impact on the change of coal to electricity and coal gas conversion policy.

Corollary A-1: The level of economic development is positively related to relationship between coal and electricity and the significance of coal and gas reform.

Corollary B-1: Environmental governance is positively related to the relationship between coal -to-electricity and coal-to-gas reform.

Table 2. Gender and household registration

\begin{tabular}{l|l|l|l|l|l}
\hline Variable & Sample size & Average value & Std. & Min & Max \\
\hline Household registration & 498 & 0.00000 & 3.390002 & 0 & 1 \\
\hline Gender & 498 & 0.43333 & 3.499117 & 0 & 1 \\
\hline
\end{tabular}

The total number of data is 498 , non-agricultural accounts for 0 , agricultural population accounts for $100 \%$ of the total data, and all respondents are rural agricultural population; males account for about $43 \%$, females account for about $57 \%$; the sample size distribution is reasonable.

Table 3. Overall understanding

\begin{tabular}{l|l|l|l|l|l}
\hline variable & Sample size & average value & Standard deviation & Min & $\max$ \\
\hline overall evaluation & 498 & 3.416667 & .8885651 & 1 & 5 \\
\hline Help level & 498 & 2.183333 & .6241378 & 1 & 3 \\
\hline Get policy subsidies & 498 & .3166667 & .4691018 & 0 & 1 \\
\hline Affordable & 498 & .3833333 & .4903014 & 0 & 1 \\
\hline High sense of offers & 498 & .6666667 & .4753827 & 0 & 1 \\
\hline
\end{tabular}


As shown in Table 3, the average value of the overall evaluation of coal-to-gas and coal-to-electricity conversion policies by farmers is about 3.42, with the highest value being 5 and the minimum value being 1 point. There are still some farmers dissatisfied with the coal-to-gas conversion policy; most farmers believe that the coal conversion gas policy has helped them and both deserve to be divided into 2.18 points with a maximum of 3 points and a minimum of 1 point. This shows that some farmers think that the coal-to-coal gas conversion policy has not helped them well. About $32 \%$ think they have received a policy subsidy, and quite a few have received a policy subsidy; about $38 \%$ believe that the coal conversion gas policy has not benefited from the initial stage; about $67 \%$ believe that Satisfaction with policy related economic subsidies is higher than that without policy subsidies.

Table 4. The main reason for affecting the sense of acquisition

\begin{tabular}{l|l|l|l}
\hline $\begin{array}{l}\text { Do you think that the main reason that affects } \\
\text { your perception of coal reform (gas) is }\end{array}$ & Frequency & Percentage & $\begin{array}{l}\text { Cumulative } \\
\text { percentage }\end{array}$ \\
\hline Other reasons & 91 & 18.33 & 18.33 \\
\hline Economic benefits & 183 & 36.67 & 55.00 \\
\hline Improvement of the environment & 224 & 45.00 & 100.00 \\
\hline Total & 498 & 100.00 & \\
\hline
\end{tabular}

As shown in Table 4, in the sample, $45 \%$ of farmers and 224 people think that the main reason for their influence on coal reform (gas) is environmental improvement; $36.67 \%$ of farmers, and 183 people think it affects them. The main reason for the acquisition of coal (gas) is the level of economic incentives; $18.33 \%$ of farmers and 91 people think that the main reason for their influence on coal reform (gas) acquisition is due to other reasons, such as high expectations for policies.

From the data analysis, it can be seen that the main factor affecting the villagers' sense of acquisition is the improvement of the environment, and the secondary factor is the economic factor. It can be seen that the environmental factors are increasingly important in the hearts of rural villagers.

\subsection{Match correlation analysis}

Table 5. Correlation of variables

\begin{tabular}{l|l|l|l|l|l|l}
\hline & $\begin{array}{l}\text { Overall } \\
\text { evaluation }\end{array}$ & $\begin{array}{l}\text { Degree of } \\
\text { help }\end{array}$ & $\begin{array}{l}\text { Get } \\
\text { subsidies }\end{array}$ & $\begin{array}{l}\text { Have } \\
\text { benefits }\end{array}$ & $\begin{array}{l}\text { Household } \\
\text { registration }\end{array}$ & $\begin{array}{l}\text { Sense of } \\
\text { preference }\end{array}$ \\
\hline Overall evaluation & 1.0000 & & & & & \\
\hline Degree of help & $0.4406^{*}$ & 1.0000 & & & & \\
\hline Get subsidies & $0.3287^{*}$ & 0.1457 & 1.0000 & & & \\
\hline Policy benefits & $0.2885^{*}$ & $0.4865^{*}$ & $0.2739^{*}$ & 1.0000 & & \\
\hline Household registration & 0.0204 & 0.2076 & -0.0448 & -0.0192 & 1.0000 & \\
\hline High sense of gain & 0.0134 & 0.1523 & 0.2533 & $0.2666^{*}$ & -0.0305 & 1.0000 \\
\hline
\end{tabular}

According to Table 5 the degree of help has a significant impact on the overall evaluation and has a positive correlation. Whether or not a policy subsidy has a significant impact on the overall evaluation is positively correlated; whether to enjoy the benefits of the policy is significant for the overall evaluation and has a positive correlation. The degree of assistance has a significant impact on obtaining a policy subsidy is positively correlated .whether or not a policy subsidy has a significant impact on whether or not to enjoy the benefits of the policy is positively related to the issue.

From Table 6, it can be seen that environmental governance has a significant impact on the sense of acquisition and has a positive correlation; the economic level has a significant influence on the sense of acquisition and has a positive correlation; wage levels have a significant impact on the sense of acquisition and have a positive correlation. The wage level has a significant impact on the economic level and there is a positive correlation. There is a significant influence on the economic 
level and environmental governance, and there is a positive correlation.

Table 6. The correlation between variables and acquired feelings

\begin{tabular}{l|l|l|l|l}
\hline & Sense of gain & $\begin{array}{l}\text { Environmental } \\
\text { governance }\end{array}$ & Economic level & Wages \\
\hline Influence reason & 1.0000 & & & \\
\hline Environmental governance & $0.1166^{*}$ & 1.0000 & & \\
\hline Economic level & $0.0850^{*}$ & $0.3664^{*}$ & 1.0000 & 1.0000 \\
\hline Wages & $0.1347^{*}$ & 0.1311 & $0.3737^{*}$ & \\
\hline
\end{tabular}

\section{Results}

According to Table 3, it can be seen that the main factor affecting the sense of obtaining the villagers is the improvement of the environment, and the secondary factor is the economic factor. The economic life has an impact on the change of coal to electricity and coal to gas conversion policies. At the same time, environmental factors have become increasingly important in the hearts of rural villagers. From the data analysis in Table 3, it can be seen that the main factor affecting the villagers' sense of acquisition is the improvement of the environment, which shows that the ecological life has an impact on the change of coal into electricity (gas) policies. From Table 1-6, it can be seen that environmental governance has a significant influence on the sense of acquisition and has a positive correlation.

\section{Conclusion}

The environmental factors that affect farmers' choice of coal to gas are greater than the economic incentives. Therefore, we must pay more attention to the environment. On the one hand, we must use coal to change the electricity (gas) policy to carry out extensive publicity and in-depth implementation of rural areas. On the other hand, during the implementation of the policy, efforts are made to reduce the annual PM2.5 concentration and improve the number of days with good air quality. Environmental quality assessment must be carried out in areas where the coal-to-electricity (gas) policy has been implemented, and the results are publicized. Promote coal to electricity (gas) injection power in northern regions.

In the implementation process of coal to electricity (gas) policy, we must pay attention to the factors of economic level and wage level. It is necessary not only to subsidize the cost of equipment, but also to focus on the development of the local economy. The development of wind power photovoltaic resources in rural areas where conditions permit can not only stimulate the development of the local economy, but also better implement the coal electricity (gas) policy.

The current coal-to-electricity (gas) policy still has many problems. Most people think that the main problem in the implementation of coal reform (gas) policy is the high cost of equipment, the secondary problem is that the average annual concentration of PM2.5 has not declined; there is also a considerable proportion of after-sales service quality, room temperature issues and policy advocacy. Therefore, the implementation of policies must focus on improving the quality of after-sales service, increasing policy publicity, and upgrading equipment to solve the problem of good room temperature.

\section{References}

[1] Chen Haiyu. Research on the Construction of Evaluation Index System for Laborers' Acquisition of Achievement under the View of Marx's Labor Value Theory [J]. Productivity Research, 2018 (03): 7-11+161. (In Chinese)

[2] Pin, ZHANG. The Theoretical Connotation and Contemporary Value of "Achieving Sense" [J]. Journal of Henan Polytechnic University (Social Science), 2016, 17 (04): 402-407. (In Chinese) 
[3] LI Zengting. "Coal to Electricity": Continuity and Dispute Continuing [J]. Appliances, 2016 (08): 24. (In Chinese)

[4] Wang Shancai. "Coal to gas" is right and wrong [J]. Ecological economy, 2018, 34 (02): 10-13. (In Chinese) 